\title{
Folktales Hegemony in the Culture of Osing Tribe in Banyuwangi - East Java
}

\author{
Pradibta Mega Ninda* \\ Indonesian Language and Literature Education of Graduate \\ School \\ Universitas Negeri Yogyakarta \\ Yogyakarta, Indonesia \\ pradibtamega.2018@student.uny.ac.id
}

\author{
Burhan Nurgiyantoro \\ Indonesian Language and Literature Education of Graduate \\ School \\ Universitas Negeri Yogyakarta \\ Yogyakarta, Indonesia \\ burhan@uny.ac.id
}

Lembu Sakti 3) Agung Sulung and Sulung Agung and 4) Macan Putih.

\section{LITERATURE REVIEW}

Research of literature sociology coupes some social theories. One of them is hegemony by Antonio Gramsci. The essence of hegemony is a form of influence in social life. The theory of hegemony by Gramsci is built on a premise of the importance of ideas and the incapability of physical power as control of social politic, this is what is meant by Gramsci with hegemony or dominating with intellectual and moral leadership (Sugiono, 2006:31). Wrote the concept of hegemony, "the supremacy of a social group manifests itself in two ways, as "domination" and as "intellectual and moral leadership". It is clear that supremacy shows totality that is supported by two concepts, they are leadership and domination (Gramsci (1999:212-213).

Ideology in the form of ideas can be identified through the analysis process. In this research, the ideology analysis will be done based on the procedure from Thompson (21014:189-194). That the procedure based on ideology analysis is divided into three basic phases, they are social analysis, discursive analysis, and interpretation. First, social analysis is a form of searching for historical circumstances and positions of figures in a social institution. Both forms of ideological discourse are studied as narratives that display certain logic. Argumentative stories are told by showing the greatness of those who have power and try to perpetuate (Thompson in Yaqin, 2014: 191). Third, rooted interpretation. The last phase relates the argumentative discourse with the relation of domination that wants to be maintained is the task of interpretation (Thompson in Yaqin, 2014: 193). This phase will provide a meeting point for the existence of an ideology about what is a background and what is its purpose. Essentially, literature does not describe an occurrence directly, literature conveys its meaning implicitly (Walta, 2019). The implicit meaning of a folktale is a step in the process of ideology embedding to children of Osing tribe through their folktales.

Proper documentation is used as a data collector if the information collected is sourced from documents (Moehnilabib, 2003: 96). The documentation technique is used to collect data in the form of quotations from the dialogue of figures and paragraphs that show a discussion of ideological hegemony and language hegemony. In descriptive qualitative research, there are steps in data analysis performed. analysis of 
data about literary texts will lead to interpretation (Endraswara, 2011: 115). Interpreting literary works means capturing meaning, explaining what is implied by expressing one's own opinion. Usually, the interpretation is centered on things that are vague such as ambiguity, figurative, symbols and other means of rhetoric to make clear the meaning or meaning of literary works (Suroso, 2009: 63-64). The analysis step takes the documentation method (Miles and Hubberman, 1979: 23) and is adjusted to the literary analysis method according to the research needs.

Meanwhile, this research has relevance with research from Walta (2019) with the title Freudian Psychoanalysis and the African Folktale. This research explains that folktale could influence the psychology of children even until they have grown up. It led the researchers to do deeper research to prove that folktales could influence one psychology until he has grown up, the researchers also question whether folktales could be messages in the social life of a region because the different region has a different story. Therefore, the title of the research is Folktales Hegemony in Social Life of the Osing Tribe in Banyuwangi.

The research type used in this research is qualitative research with documentation techniques. The implementation of this qualitative method is used in analyzing hegemony ideology in folktales of Banyuwangi. The draft that is used in this research is literature sociology. The descriptive analysis method gives an overview of a story followed by an explanation of content analysis (Ratna, 2004:53). The resources of the research are 1) Folktales of Banyuwangi (Hutomo, 1996) literature theory of hegemony Gramsci 3) and other supporting kinds of literature.

\section{RESULTS AND DISCUSSIONS}

In this chapter, there will be overviews of folktales, then the meanings related to hegemony will be taken, and it will be followed by the results of the analysis. Meanwhile, the explanations will be as follows:

\section{A. Sritanjung}

The story of Sritanjung is the most memorable story for people of Osing tribe. The reason is the story tells the origin of the name of Banyuwangi. The story began when a prime minister of the Blambangan Kingdom named Sidopekso hunted a young deer on a request of the king. He met a beautiful woman named Sritanjung. They got married. The king was also falling in love with Sritanjung, then he defamed Sritanjung to make Sidopekso left her side. The King said that Sritanjung had seduced him. What happened next was unexpected. Sidopekso killed her wife. Regret came later. There came fragrant from the river where the body was washed away. It showed that Sritanjung was not guilty.

This folktale explains the origin of the name of Banyuwangi which has the meaning of scented water. Generally, this story is full of representation to protect one's dignity. It is shown in the following words "if the water becomes fishy then my wife is guilty but if the water becomes fragrant then Sritanjung is innocence" (Hutomo, 1996). In the recipe, it can be seen that Sidopekso tried to protect his name to prove the innocence. Besides, he proved himself as a husband that had been betrayed. He killed his wife because she had done something wrong that broke his reputation.

The folktale of Sritanjung gives a strong hegemony in creating views of the life of people of Osing. Loyalty, keep one's reputation, and loyalty to the ruler are important things in life. This strong identity will strengthen the willing to preserve the region's existence

\section{B. Lembu Setata and Lembu Sakti}

Lembu Setata and Lembu Sakti are brothers. This folk tale tells a story of those two people and their descendants that cleared forests to become fields. The fields were used as places for farming to meet the need for food. The story focuses on the ideal order of family life for people of Osing. " On the day of Soma Manis, Besar moth, wuku Kuranthil, Wawu year and Windu Kuntara, the family went to forests to clear them.....they have no distraught or envy each other in working hard" (Hutomo, 1996).

The overview explains the representation of the ideal family in people of Osing that the meaning of family is to be together as a big family; it's not a small family that stands alone. Besides, a detailed message implicitly tells that every family has to choose the best day to begin something. It can be seen from the detailed calendaring. The choosing of Bulan Besar in the Hijrah calendar means big fortune if being done on the right days.

\section{Agung Sulung and Sulung Agung}

Agung Sulung and Sulung Agung are teachers of princes. But they left the kingdom because they felt that they have educated a prince that didn't reflect a king trait, that was wisdom. They left the kingdom to atone their guilty feeling. Agung Sulung went to the north to Cungking and became a teacher for a commoner (History of Mbah Buyut Cungking) and Sulung Agung went to the south, he decided to clear the forests that later became the origin of names of villages in Southern Banyuwangi. His journey was stopped when he wanted to own a water jug that belonged to a widow. That was the only wealth that she had so she didn't want anyone else to own it. Because of that Sulung Agung married that woman and live permanently.

This folktale has a message for the youngers. "after the wedding party that was held modestly, Sulung Agung promised her wife and his best friends that he would not travel anymore because he felt enough (Hutomo, 1996). The first moral value that can be taken from the story is one needs to be brave enough to do traveling to get experiences but before that, one must have knowledge or broadminded. It can be seen from his earlier work as a teacher. This comprehension in people of Osing makes them understand how important knowledge is so that they will not get lost while traveling.

Second, daily needs have to be settled first so that one, after marriage, could live properly. This phenomenon is shown by Sulung Agung in clearing the forests so that the land could be 
used for farming by his descendants. When the material needs were enough then Sulung Agung got married.

The wedding party was held modestly and he married a widow of a water jug that he wanted to own. In this part, we can see that in a social relationship especially in a marriage matter, social status is not considered. People of Osing tend to judge from traits. The water jug that belonged to the widow shows that she could keep what she had carefully. Water is the source of life. Therefore, Sulung Agung married her because she could be a life for him. The modest wedding party shows that a ceremony doesn't have to scatter what we have in life.

Third, Sulung decided that after marriage he will live permanently, he will not leave her wife and his best friends. This is an ideal family relationship based on people of Osing views. A patriarch must protect, educate his descendants, and welfare his family.

\section{Macan Putih (White Tiger)}

The story of Macan Putih began when King Tawang Alun finished his meditation. He received a message from God to build a new kingdom. When he was thinking of where should the new kingdom was, he was surprised by a white tiger. The tiger was tame and could talk; the white tiger offered its back to being ridden by Tawang Alun. When king Tawang Alun got on the back of the white tiger, he was brought in a flash to a faraway place in eastern Java. When the king got there, he fell asleep under a Banyan tree for the weather was so cool. In his dream, the king received an order to build the new kingdom here and the king would receive an extension of age for fifty years. The king started to build the new kingdom immediately helped by brothers from the Atas Angin kingdom named Simo Sardulo.

This folktale explains the origin of Banyuwangi being opened to be habited while it was at first a wild forest in eastern Java. Geographically Banyuwangi was an isolated area where the northern part, the eastern part, and the southern part were bordered by the sea while the western part was bordered by a volcano. This makes people of Osing believe that one who could clear the forest was a magical man that was guided by God. They think that a normal human being will not be able to get close to the volcano. It is a miracle that someone could cross the volcano crater and sulfur.

The hegemony of this story shows that there is a power that rules macrocosm, in this concept is God. "That old man said that his meditation was accepted by Hyang Widi and the age of the king was added fifty years" (Hutomo, 1996). This creates a belief that as a human we have to ask or pray to God to have the right path in life and do a big thing that can be useful for all.

Based on the story, people of Osing are required to have a religion or to have a spiritual belief that God as the creator of the universe exists and God knows everything. Meditation in the forest of Banyuwangi called Alas Purwo still exists nowadays for some people who are willing to do big things such as to get a position in government or to receive an oracle of the future. Besides, mythical creatures are believed to have power more than a human being but some of them can be ordered to do human wish. Nowadays it is still believed that someone that is considered as a magical man who has power more than normal people are helped by mythical creatures.

\section{CONCLUSION}

Based on the discussions above, it can be seen that people of Osing have an oral tradition which is folktales about the naming of a place, history of Blambangan Kingdom, colonialism, ideal order of family, and relationship among humans. The story of Sritanjung focuses on how the city order the kingdom is and the belief of commitment in a relationship. Lembu Setata and Lembu Sakti tell about a family that gets along well. Agung Sulung and Sulung Agung is a representation of a life process of an ideal man, about some things that have to be done and can be achieved since a young age to old time. Macan Putih tells about belief to God as the Creator and mystical creatures that help human life. All of the stories can be teachings on how the ideal social life based on people of Osing in Banyuwangi is and can be hegemony control for the cultural preservation of the tribe.

\section{ACKNOWLEDGMENTS}

Thanks to all people who provide moral and material support and guide us in carrying out this research.

\section{REFERENCES}

Endraswara, Suwardi. 2011. Drama Learning Methods (Appreciation, Expression, and Assessment). Yogyakarta: CAPS. Endraswara, Suwardi. 2011. Metode Pembelajaran Drama (Apresiasi, Ekspresi, dan Pengkajian). Yogyakarta: CAPS.

Gramsci, Antonio. (1999). Selections from the Prison Notebooks. London: ElecBook.

Hutomo, Sripan Sadi and Yonohudiyono E. (1996). Folktales of Banyuwangi. Jakarta: Grassindo. Hutomo, Sripan Sadi dan Yonohudiyono E. (1996). Cerita Rakyat dari Banyuwangi. Jakarta: Grassindo.

Miles, Mathew B. dan Hubberman A. Michael. 1979. Qualitative Data Analysis. London: Sage Publications Inc. Translated by Rohidi,Tjetjep Rohendi. 1992. Analisis Data Kualitatif: Buku Sumber tentang Metodemetode Baru. Jakarta: Universitas Indonesia Press.

Moehnilabib dkk. 2003. Basics of Research Methodology. Malang: Lembaga Penelitian dan Penerbit Universitas Negeri Malang. Moehnilabib dkk. 2003. Dasar- Dasar Metodologi Penelitian. Malang: Lembaga Penelitian dan Penerbit Universitas Negeri Malang.

Ratna, Nyoman Kuta. (2007). Literature and Cultural Studies: Representation of Fiction and Facts. Yogyakarta: Pustaka Pelajar. Ratna, Nyoman Kuta. (2007). Sastra dan Cultural Studies: Representasi Fiksi dan Fakta. Yogyakarta: Pustaka Pelajar.

Sugiono, Muhadi. (1999). Restructuring Hegemony and the Changing Discourse of Development. Yogyakarta: Pustaka Pelajar. Translated by Cholish. (2006). Kritik Antonio Gramsci terhadap Pembangunan Dunia Ketiga. Cetakan Kedua. Yogyakarta: Pustaka Pelajar.

Suroso, Santosa, dan Suratno. 2009. Literary Criticism: Theory, Methodology, and Application. Yogyakarta: Elmatera Publishing. Suroso, Santosa, dan Suratno. 2009. Kritik Sastra: Teori, Metodologi, dan Aplikasi. Yogyakarta: Elmatera Publishing.

Thompson, John B. (1984). Studies in the Theory of Ideology. California: University of California Press. Translated by Yaqin, Haqqul. (2014). Analisis Ideologi Dunia. Yogyakarta: IRCiSoD.

Walta, Njogu. "Freudian Psychoanalysis and the African Folktale". on Studies in English Language and Literature (IJSELL), vol 7, no. 1, 2019, pp. 23-29. 